\title{
Oral administration of sodium butyrate reduces chemically-induced preneoplastic lesions in experimental carcinogenesis
}

\author{
Administração oral de butirato de sódio \\ reduz lesões pré-neoplásicas quimicamente \\ induzidas na carcinogênese experimental
}

\author{
Maria do Carmo Gouveia PELUZIO' \\ Ana Paula Boroni MOREIRA ${ }^{1}$ \\ Isabela Campelo de QUEIROZ1 \\ Cristina Maria Ganns Chaves DIAS ${ }^{2}$ \\ Sylvia do Carmo Castro FRANCESCHINI ${ }^{1}$ \\ Jacqueline Isaura ALVAREZ-LEITE ${ }^{3}$ \\ Antônio José NATALI ${ }^{3}$ \\ Céphora Maria SABARENSE'
}


718 | M.C.G. PELUZIO et al.

the content of stearic and oleic acids in the intra-abdominal fat and docosahexaenoic acid in the liver. Moreover, these rats presented higher percentages of linoleic acid in the intra-abdominal fat than control rats.

\section{Conclusion}

The data indicate that butyrate use in rats reduced preneoplastic lesions and changes in the intra-abdominal fat and fatty acid profile of the liver, commonly found in colon carcinogenesis.

Indexing terms: Fatty acids. Butyrate. Cyclins. Colonic neoplasms, tumor markers, biological.

\section{R E S U M O}

\section{Objetivo}

Avaliar o efeito da administração oral de butirato de sódio na carcinogênese do cólon.

\section{Métodos}

A carcinogênese em ratos Wistar foi induzida com injeções de 1,2-dimetilhidrazina na dose de 40mg/kg de peso corporal. A solução de butirato de sódio (3,4\%) foi oferecida ad libitum por 4 semanas (grupo butirato, $n=16)$, em substituição à água (grupo controle, $n=9$ ). Os ratos foram sacrificados na $17^{a}$ semana após tratamento com a 1,2-dimetilhidrazina. Focos de criptas aberrantes e a expressão dos genes para o ácido ribonucléico mensageiro (RNAm) das ciclinas D1 e E foram quantificadas no cólon. Alterações no perfil de ácidos graxos do cólon, no fígado, na gordura intra-abdominal e nas fezes foram analisadas.

\section{Resultados}

Uma significante diminuição nos focos de criptas aberrantes foi encontrada no grupo que recebeu butirato. Nenhuma diferença foi encontrada na expressão do RNAm das ciclinas D1 e E entre os grupos. Contudo, a ingestão de butirato diminuiu a quantidade de ácido esteárico e ácido oléico na gordura intra-abdominal e do ácido docosahexanóico no fígado. Além disso, o grupo butirato apresentou maior percentual de ácido linoléico na gordura intra-abdominal, comparado com os ratos do grupo controle.

\section{Conclusão}

Os dados indicam que o uso de butirato reduz lesões pré-neoplásicas em ratos e diminui as alterações no perfil de ácidos graxos da gordura intra-abdominal e do fígado, comumente encontradas na carcinogênese colônica.

Termos de indexação: Ácidos graxos. Butirato. Ciclinas. Neoplasia do colon. Marcadores biológicos de tumor

\section{INTRODUCTION}

Colon cancer affects millions of people all over the world, killing more than half a million individuals each year. It is the type of cancer most affected by diet, so its prevention through diet has received great attention ${ }^{1-3}$.

The human colon is important for the fermentation of unabsorbed polysaccharides which produces Short-Chain Fatty Acids (SCFA), especially acetic, propionic and butyric acids, in a molar ratio of $\sim 60: 20: 20$ in the colon region ${ }^{4}$. This ratio may vary depending on the composition of dietary fiber. Experimental and epidemiological studies suggest that dietary fiber protects against colon cancer ${ }^{5,6}$ when consumed regularly and modulates immune responses in the intestine and intestinal microflora'.

During colon carcinogenesis, there is an increase in the expression of cyclins in the intestinal mucosa associated with abnormalities in the cell cycle progression and regulation of cell growth ${ }^{6}$. The progression of the $\mathrm{G} 1$ phase of the cell cycle is mediated by the combination of cyclin D1 activity, which binds to Cyclin-Dependent Kinase (CDK) 4 and 6, and cyclin E with cdk2, forming a complex that leads to the $S$ phase of the cell cycle $^{7,8}$.

Butyrate may explain the protective effect of soluble fibers against colon cancer. It has multiple effects on the differentiation of malignant or normal colon cells ${ }^{9}$. In vitro studies ${ }^{7,10}$ demonstrated 
that butyrate is capable of reducing mRNA expression of cyclins D1 and E, by blocking the passage of the cell from the $\mathrm{G} 1$ phase to the $S$ phase of the cell cycle and causing cellular apoptosis. However, little is known about the role of sodium butyrate in in vivo studies.

Important changes occur at the cellular and metabolic levels during a carcinogenic process in the colon. There are evidences of changes in the lipid metabolism of cancer patients, with varying percentages of fatty acids present in their blood plasma and adipose tissue ${ }^{11-13}$. Studies that assess the fatty acid profile of these patients have found that the percentages of Docosahexaenoic (DHA), oleic and stearic acid increase, and the percentage of linoleic acid deseases ${ }^{12-14}$. However, the mechanisms are unknown.

The objective of this study was to assess the effect of sodium butyrate given orally during the initial stage of colon carcinogenesis induced by 1,2 Dimethylhydrazine (DMH) in Wistar rats, regarding the presence of Aberrant Crypt Foci (ACF), expression of colon cyclins D1 and E and fatty acid profile of the colon, intra-abdominal fat, liver and feces.

\section{METHODS}

Twenty-five 11-week-old male Wistar rats with an average body weight of $250 \mathrm{~g}$ were used. The animals were housed at the Central Animal House in the Center of Biological and Health Sciences of the Universidade Federal de Viçosa, Brazil. The rats were kept in polyethylene cages (four to five rats per cage) in a room maintained at a mean temperature of $23^{\circ} \mathrm{C}$, standard deviation $=2^{\circ} \mathrm{C}$, in a $12-\mathrm{h}$ light/dark cycle. The animals were fed a commercial diet (Nuvilab, Curitiba, Brazil) proper for laboratory rodents. Body weight and food intake were monitored weekly.

The rats were divided into two groups: a control group (CG, $n=9$ ), having water ad libitum, and a butyrate group (BG, $n=16)$, having a solution of sodium butyrate ad libitum during the firsts 30 days of the experimental period. The butyrate solution was prepared by dissolving $3.4 \mathrm{~mL}$ of butyric acid (Sigma, St. Louis, USA) in $96.6 \mathrm{~mL}$ of distilled water, totaling a volume of $100 \mathrm{~mL}$. The final concentration was $372 \mathrm{mmol} / \mathrm{L}$. The $\mathrm{pH}$ was adjusted at 7.2-7.4 with $0.1 \mathrm{~N} \mathrm{NaOH}$. After four weeks of butyrate availability, all rats had water ad libitum until the end of the experiment.

Four subcutaneous injections of $\mathrm{DMH}$ obtained from Sigma (St. Louis, USA) were applied in doses of $40 \mathrm{mg} / \mathrm{Kg}$ body weight, twice a week, during the first two weeks to induce preneoplastic lesions ${ }^{15}$. DMH was dissolved immediately in a $0.9 \%$ solution of $\mathrm{NaCl}$ before mixing with a $1.5 \%$ solution of EDTA. The $\mathrm{pH}$ of the final solution was adjusted to 6.5. The rats were killed 17 weeks after the last DMH injection, after a 12 hours fast.

The colon was removed from the cecum to the rectum for ACF analysis. The liver and intraabdominal fat were collected for fatty acid profile analysis.

\section{Histopathological analysis}

After removal, the tissues were washed in saline, longitudinally opened through the antimesenteric margin, embedded in paraffin, with the mucosa facing the upper side of the slide and then fixed in 10\% formaldehyde for 24 hours. After fixation, the large intestine was measured and divided into three equal fragments denominated proximal, medial and distal, in relation to the cecum. Then the segments were stained with a $1 \%$ methylene blue solution for two minutes, and rinsed with a Phosphate Buffer (PBS) for further analysis.

The surface of the intestinal mucosa was examined under a standard light microscope (10X magnification) for ACF identification and categorization, in accordance with the technique described by Bird ${ }^{16}$. The ACF were counted in the entire mucosal surface of the large intestine, from the cecum to the rectum, by two independent observers in a double-blind manner.

The ACF were categorized by counting the foci containing three or less aberrant crypts and 
the foci with more than three aberrant crypts. In order to analyze the results, first the reduction potency was calculated, dividing the median of the ACF number of the CG rats by the ACF median of the $B G$ rats. The percentage $A C F$ reduction was then determined by the following formula:

Percentage reduction $=100-100 /$ Potency.

\section{Expression of cyclins}

In order to evaluate the effect of the butyrate on the expression of cyclins D1 and E in the colonic mucosa, six rats (three from each group) were killed immediately after the butyrate ingestion period and the large intestine was fully removed to prepare the mucosal smear.

After the butyrate ingestion period, colonic mucosal smears of the medial and distal segments were obtained, identified and immediately frozen in liquid nitrogen until analysis. Extraction of mRNA was conducted as described by Portugal et al. ${ }^{17}$ and RT-PCR analysis was adapted from Hur et al. ${ }^{18}$. The frozen tissues were prepared using Trizol (Invitrogen, Carlsbad, USA) for total mRNA extraction from the mucosa of the animals of each group. Total mRNA was quantified by spectrophotometry at $260 \mathrm{~nm}$ and the cDNA band was prepared for reverse transcriptase (RT). The cDNA was amplified by PCR using HPRT, cyclin D1 and cyclin E primers. The reaction was conducted in a thermocycler with $9 \mu$ of mix for the $P C R$ reaction containing $2.5 \mathrm{mM}$ DNTP, Taq Buffer with $15 \mathrm{mM}$ of $\mathrm{MgCl}_{2}$, Taq DNA polymerase and primer sense and anti-sense 1:1 mixture. The samples were first incubated at $95^{\circ} \mathrm{C}$ for $3 \mathrm{~min}$ and denatured at $94^{\circ} \mathrm{C}$ for $1 \mathrm{~min}$ annealing followed by 2 min extension at $72^{\circ} \mathrm{C}$. After the end of the program with the number of cycles determined for each primer, the program performed an extension of $72^{\circ} \mathrm{C}$ for $7 \mathrm{~min}$. Nucleotide sequences, PCR product sizes, annealing temperature and number of cycles for each primer are as follows: cyclin D1, sense 5'-TGGAGCCCCTGAAGAAGAG3 ' and anti-sense 5'-AAGTGCGTTGTGCGGTAGC$3^{\prime}, 60^{\circ} \mathrm{C}, 34$ cycles. Cyclin E, sense $5^{\prime}$-CTGGC
TGAATGAATGTTTATGTCC-3', anti-sense 5'TCTTTGCTTGGGCTTTGTCC-3', 60 $\mathrm{C}$, 34 cycles. HPRT sense 5'-GTTGGATACAGGCCAGA CTTTGTTG-3' and anti-sense 5'-GATTCAACTT GCGCTCATCTTAGGC-3', 58 $\mathrm{C}$, 35 cycles. After amplification, the PCR products were separated by polyacrylamide gel (6\%) and stained with silver nitrate. The intensity of each band was measured by densitometry using the specific program (Gel Expert ${ }^{\circledR}$, Nucleotech) and the data was expressed in arbitrary units.

\section{Fatty acid analysis}

The colon, liver and intra-abdominal fat were frozen immediately after removal and kept at $-20^{\circ} \mathrm{C}$ until analysis. In order to determine the long chain fatty acid profile of these tissues, their lipids were extracted according to the method described by Folch et al. ${ }^{19}$ and methylated according to Hartman \& Lago's technique ${ }^{20}$.

The identification of the fatty acid methyl esters was performed by gas chromatography, by comparing the retention time of the sample esters with the reference patterns (Sigma-Aldrich, St. Louis, USA), using the gas chromatographer GC 17 A Shimadzu/Class GC 10 equipped with a fused silica chromatographic column SP-2560 of $100 \mathrm{~mm} \times 0.25 \mathrm{~mm}$ internal diameter and flame ionization detector. The results were expressed as the percentage of total fatty acids.

The fecal content of short chain fatty acids (acetic, propionic and butyric acids) were quantified in accordance with the method described by Tangerman \& Nagengast ${ }^{21}$. A gas chromatographer GC 17 A, Shimadzu/Class GC equipped with a chromatographic column Nukol with an internal diameter of $30 \mathrm{~m} \times 0.25 \mathrm{~mm}$ was used (Supelco, Inc., Bellefonte, PA). A calibration curve was generated to account for the SCFA.

The Sigma Stat software, version 2.03, was used for the statistical analysis. The data were initially analyzed using the Kolmogorov-Smirnov 
test to verify their symmetry. The $t$ test or the Mann-Whitney test were used to compare two independent groups, and the Kruskal-Wallis test was used to compare three independent groups, complemented by the Dunn's multiple comparison procedure. Significance was set at $p<0.05$.

The experiment respected the Ethical Principles and Guidelines for Experiments on Animals, adopted by the Declaration of Helsinki (2000) and by the Brazilian College on Animal Experimentation (COBEA).

\section{RE S U L T S}

\section{Food intake and weight}

There was no significant difference in food intake between BG and CG ( $p>0.05)$. The animal weights were similar in both groups throughout the experiment $(p>0.05)$. The average butyrate intake was $17.1 \mathrm{mmol} /$ day for each animal.

Rats treated with butyrate for 4 weeks had $51.4 \%$ fewer ACF per whole colon compared with

Table 1. Effect of butyrate on number of 1.2-dimethylhydrazine induced aberrant crypt foci and crypt multiplicity in the large intestine of male Wistar rats. Universidade Federal de Viçosa (MG), 2005.

\begin{tabular}{|c|c|c|c|c|c|c|}
\hline \multirow{2}{*}{ Group } & \multirow{2}{*}{ Total ACF } & \multirow{2}{*}{ Foci $\leq 3$ aberrant crypts } & \multirow{2}{*}{ Foci>3 aberrant crypts } & \multicolumn{3}{|c|}{ Total ACF/Segment ${ }^{\mathbf{b}}$} \\
\hline & & & & Proximal & Medial & Distal \\
\hline Control & 207.0 & 166.0 & 32.0 & 27.0 & 90.0 & 74.0 \\
\hline Butyrate* $^{*}$ & 100.5 & 77.5 & 21.5 & 18.5 & 50.5 & 34.0 \\
\hline$p^{\mathrm{a}}$ & 0.006 & 0.004 & 0.336 & 0.203 & 0.002 & 0.051 \\
\hline
\end{tabular}

Results expressed by the median. Control group ( $n=9)$ and Butyrate group ( $n=16)$. ACF: aberrant crypts foci.

* Oral butyrate $(3.4 \mathrm{~mL} \%)$ was given only during the first weeks of the experiment. ${ }^{\mathrm{a}} p$ value of the comparasion between control group and butyrate group by Mann-Whitney test; ${ }^{\mathbf{b}}$ Comparison of the proximal, medial and distal segments for each group was analyzed by Kruskal-Wallis test. Significant differences were verified $(p<0.001)$. And the distal numbers were higher than of the medial and proximal segments (Dunn's test).

Table 2. Effect of butyrate on main fatty acid contents of the intra-abdominal fat of the male Wistar rats, 17 weeks after 1.2 dimethylhydrazine administration. Universidade Federal de Viçosa (MG), 2005.

\begin{tabular}{lccc}
\hline Fatty acid & Control group [\% total fatty acid] & Butyrate group\# [\% total fatty acid] & Value of $p^{*}$ \\
\hline C16:0 (palmitic) & 30.27 & 23.59 & 0.064 \\
C18:0 (stearic) & 4.40 & 3.52 & 0.009 \\
C18:1n9 (oleic) & 44.58 & 34.16 & 0.001 \\
C18:2n6 (linoleic) & 14.44 & 29.71 & 0.013 \\
\hline
\end{tabular}

\# Oral butyrate (3.4\%) was given during 4 weeks and then replaced by water; "Man Whitney test.

Table 3. Effect of butyrate on main fatty acid contents of the liver of the male Wistar rats, 17 weeks after 1.2-dimethylhydrazine administration. Universidade Federal de Viçosa (MG), 2005.

\begin{tabular}{lccc}
\hline Fatty acid & Control group [\% total fatty acid] & Butyrate group\# [\% total fatty acid] & Value of $p^{*}$ \\
\hline C16:0 (palmitic) & 16.98 & 19.30 & 0.171 \\
C18:0 (stearic) & 13.42 & 14.80 & 0.210 \\
C18:1n-9 (oleic) & 12.12 & 10.69 & 0.162 \\
C18:2n-6 (linoleic) & 20.68 & 20.93 & 0.560 \\
C18:3n-3 (linolenic) & 0.81 & 0.77 & 0.589 \\
C20:4n-6 (arachidonic) & 24.24 & 24.74 & 0.546 \\
C20:6n-3 (docosahexaenoic) & 10.36 & 8.17 & 0.039 \\
\hline
\end{tabular}

\# Oral butyrate (3.4\%) was given during 4 weeks and then replaced by water; "Man Whitney test. 


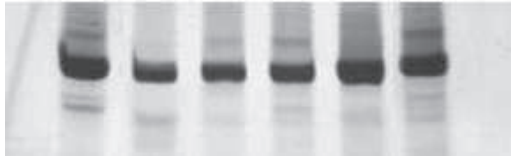

Cyclin D1

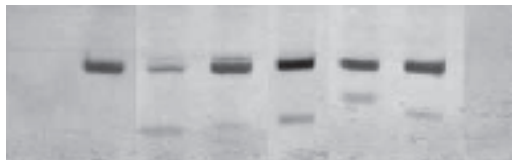

Cyclin E

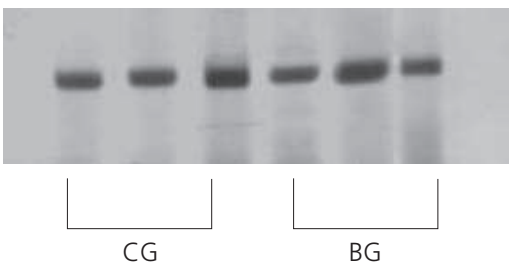

HPRT

$1 \mathrm{~A}$
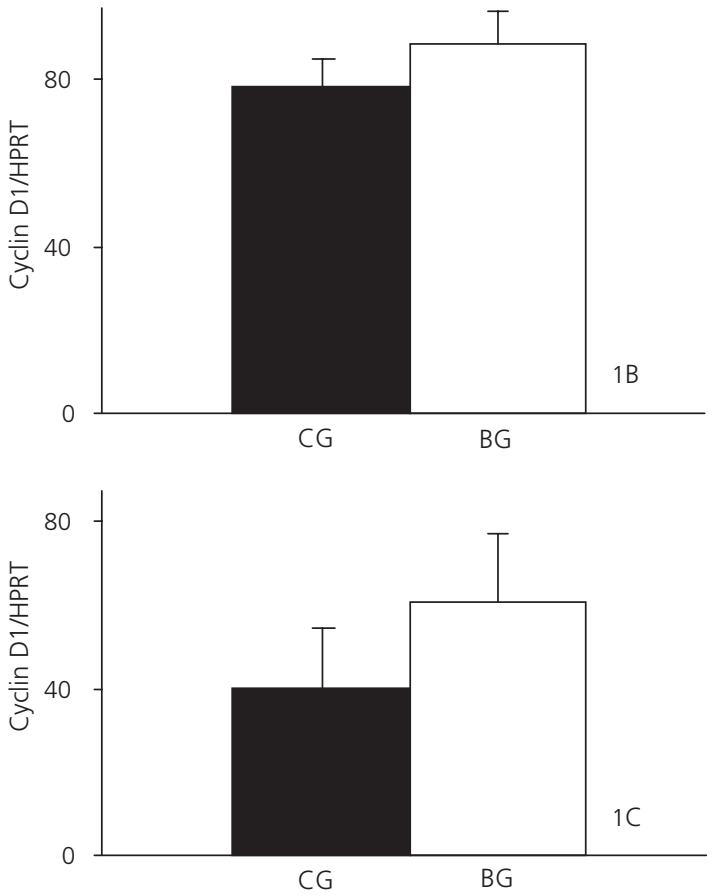

Figure 1. Messenger ribonucleic acid (mRNA) content of cyclin D1 and cyclin $\mathrm{E}$ in the colonic mucosa of male Wistar rats 17 weeks after 1.2-dimethylhydrazine (DMH) administration. Universidade Federal de Viçosa (MG), 2005.

Note: The messenger ribonucleic acid (mRNA) content of cyclin D1 and cyclin $\mathrm{E}$ was estimated by reverse transcription polymerase chain reaction (RT-PCR), using hypoxanthine phosphoribosyltransferase (HPRT) as internal control in the colonic mucosa. (A) Representative inverted images of PCR product in the colonic mucosa of the control (CG) and butyrate (BG) groups. The PCR products were separated by SDS-PAGE $(6 \%)$ and stained with silver nitrate. (B) Cyclin D1 mRNA levels in the colon mucosa of the control (CG) and butyrate (BG) groups. (C) Cyclin E mRNA levels in the colon mucosa of the control (CG) and butyrate (BG) groups. Quantification of PCR signals was obtained by densitometry using the program Gel Expert-Nucleotech.
CG rats. There was no significant effect of butyrate on crypt multiplicity within the ACF. When the large intestine was analyzed by segment, BG rats had a $31.5 \%$ reduction in total $A C F$ in the proximal segment, $43.9 \%$ in the medial segment and $54.41 \%$ in the distal segment compared with CG (Table 1).

No difference was found in the intensity and extension of the cyclin D1 and E bands between BG and CG rats ( $p=0.400$ and $p=0.534$, respectively), as shown in Figure 1.

A lower percentage of the stearic and oleic acids was found in the intra-abdominal fat of the BG (Table 2). On the other hand, the percentage of linoleic acid in the intra-abdominal fat was higher in the BG than in the control group. When liver fatty acids were analyzed, only DHA was lower in the $B G$ than in the $C G$ (Table 3). Nevertheless, the percentage of the other fatty acids investigated was not different between groups, nor was the percentage of the colonic fatty acids. In relation to the fecal fatty acids, differences in acetic, propionic and butyric acid content between the two studied groups were not observed (Table 4).

\section{DISCUSSION}

The ACF were observed mainly in the medial and distal segments, as also described by Rodrigues et $a l .{ }^{15}$. The butyrate, given only in the initial phase, was able to reduce total ACF by more than $50 \%$, confirming its beneficial effect in chemically-induced colon cancer as shown by other experimental studies ${ }^{6,22}$. However, Freeman ${ }^{23}$ found an increased tumor incidence in rats treated for 12 weeks with $\mathrm{DMH}$. The difference in this result could be due to the lower butyrate concentration in the experimental period after $\mathrm{DMH}$ treatment. The butyrate concentrations reported in earlier studies are quite varied with no consensus for an optimal supplementation dose. In vitro studies ${ }^{7,24,25}$ tested butyrate concentrations of 1 to $25 \mathrm{mM}$, whereas experimental and clinical 
Table 4. Effect of butyrate on main short chain fatty acids contents of feces of male Wistar rats, 17 weeks after 1.2-dimethylhydrazine administration. Universidade Federal de Viçosa (MG), 2005.

\begin{tabular}{lccc}
\hline Short-chain fatty acid & Control group $[\mathrm{mg} / \mathrm{kg}$ feces] & Butyrate group ${ }^{\#}[\mathrm{mg} / \mathrm{kg}$ feces] & Value of $p^{*}$ \\
\hline Acetic acid & 0.77 & 0.71 & 0.815 \\
Propionic acid & 0.19 & 0.17 & 0.815 \\
Butyric acid & 0.14 & 0.11 & 0.699 \\
\hline
\end{tabular}

\# Oral butyrate (3.4\%) was given during 4 weeks and then replaced by water; * Man Whitney test.

studies tested concentrations of up to $100 \mathrm{mg} / \mathrm{Kg}$ of body weight per day ${ }^{26,27}$.

Butyrate is said to down-regulate the expression of cell cycle regulators, inhibiting the proliferation and inducing apoptosis in in vitro colon cancer cells ${ }^{28}$. Since genomic alterations characteristic of the carcinogenic process may occur as soon as two weeks after DMH induction ${ }^{15}$, the present study investigated the effect of butyrate supplementation on the expression of cyclins D1 and $E$ at the end of the butyrate administration period. However, differences in cyclin expression in the intestinal mucosa could not be detected by RT-PCR. The period chosen for analysis of the cyclins (two weeks after lesion induction) is probably not enough to detect changes in cyclin expression or perhaps having used an entire segment of the large intestine made the detection difficult in case of discrete changes. In a preliminary study done by our group, twice the concentration was used with the intent of assessing cyclin expressions, but the animals did not survive the doses. Otori et al. ${ }^{29}$ identified the expression of cyclin D1 when using ACF with more than seven crypts. Other mechanisms may be involved in the beneficial effect of sodium butyrate on colon preneoplastic lesions. In vitro studies demonstrated that butyrate can induce apoptosis through caspase-3 activation ${ }^{9,28}$ or increase p21 and p27 expressions, which are negative regulators of the cell cycle $25,30,31$.

Several studies ${ }^{11,14}$ reported fatty acid metabolism changes in colon cancer patients such as an increase in DHA, stearic and oleic acids and a reduction in linoleic acid content. Changes, such as reduced lipid peroxidation, which is characteristic of cell growth, lead to increased DHA concentration in tumor tissue ${ }^{11}$. This study showed an improvement in the fatty acid profiles of butyrate-treated rats, due to reduced DHA in the liver and reduced stearic and oleic acid and increased linoleic acid in the intra-abdominal fat. The intra-abdominal fatty acids have a slow turnover and their composition depends on dietary intake $\mathrm{e}^{32}$. Our results are in accordance with Topping \& Clifton ${ }^{33}$ that report similar concentration levels, respectively, acetic $>$ propionic $>$ butyric acids. The SCFA are quickly metabolized and butyrate is one of the most important energy sources used by the colonocytes. Considering the reduced content of butyrate in the feces of both groups, it was likely well used by the colonocytes of the animals given the butyrate solution.

In conclusion, sodium butyrate intake reduced the number of preneoplastic lesions 17 weeks after $\mathrm{DMH}$ treatment and reduced the changes that occur in the intra-abdominal and liver lipid profiles caused by the carcinogenic process in Wistar rats. The results of this investigation suggest that oral butyrate is able to protect the intestinal mucosa from chemical carcinogenic lesions.

\section{ACKNOWLEDGMENTS}

This study was sponsored by Fundação de Desenvolvimento à Pesquisa de Minas Gerais (CDS 996/2004). Jacqueline Isaura Alvarez-Leite has a research fellowship from the Conselho Nacional de Desenvolvimento Científico e Tecnológico (CNPq) Brazil. Thanks to Jeffrey R. Oar for reviewing the English of this text. 
724 | M.C.G. PELUZIO et al.

\section{OLLABORATORS}

M.C.G. PELUZIO mentor and coordinator of the research project, supervised the master degree students Ana Paula Boroni Moreira and Isabela Campelo de Queiroz. A.P.B. MOREIRA master degree student, collaborated with the writing and review of this manuscript. I.C. QUEIROZ master degree student, responsible for the execution of the experimental assay. C.M.G.C. DIAS co-supervised the project and was responsible for the standardization of the colon cancer-induction protocol. S.C.C. FRANCESCHINI cOsupervised the project and collaborated with the statistical analysis. J.I. ALVAREZ-LEITE co-supervised the project and was responsible for the standardization of the cyclins determination protocol. A.J. NATALI co-supervised the project and reviewed the final manuscript. C.M. SABARENSE co-supervised the project, standardized the fatty acids profile determination protocol and collaborated with the final review of the manuscript.

\section{REFERENCES}

1. Brouns F, Kettlitz B, Arrigoni E. Resistant starch and "the butyrate revolution". Trends Food Sci Technol. 2002; 13(8):251-61. doi: 10.1016/S09242244(02) 00131-0.

2. Bingham SA, Day NE, Luben R, Ferrari P, Slimani N, Norat $T$, et al. Dietary fibre in food and protection against colorectal cancer in the European Prospective Investigation into Cancer and Nutrition (EPIC): an observational study. Lancet. 2003; 361(9368):1496-501. doi: 10.1016/S0140-6736 (03)13174-1.

3. Peters $U$, Sinha R, Chatterjee $N$, Subar AF, Ziegler RG, Kulldorff, M, et al. Dietary fibre and colorectal adenoma in a colorectal cancer early. Lancet. 2003; 361(9368):1491-5. doi: 10.1016/S0140-6736(03) 13173-X.

4. Cummings JH, Pomare EW, Branch WJ, Naylor CP, McFarlane GT. Short chain fatty acids in human large intestinal, portal, hepatic and venous blood. Gut. 1987; 28(10):1221-7. doi: 10.1136/gut. 28.10.1221.

5. Grasten SM, Juntunen KS, Poutanen KS, Gylling HK, Miettinen TA, Mykkanen HM. Rye bread improves bowel function and decreases the concentration of some compounds that are putative colon cancer risk markers in middle-aged women and men. J Nutr. 2000; 130(9):2215-21.
6. Hu Y, Martin J, Leu RL, Young GP. The colonic response to genotoxic carcinogens in the rat: regulation by dietary fibre. Carcinogenesis. 2002; 23(7):1131-7.

7. Coradini D, Pellizzaro C, Marimpietri D, Abolafio G, Daidone MG. Sodium butyrate modulates cell cycle-related proteins in HT29 human colonic adenocarcinoma cells. Cell Prolif. 2000; 33(3): 139-46. doi: 10.1046/j.1365-2184.2000.00173.x.

8. Bardon S, Foussard V, Fournel S, Loubat A. Monoterpenes inhibit proliferation of human colon cancer cells by modulating cell cycle-related protein expression. Cancer Lett. 2002; 181(2): 187-94. doi: 10.1016/S0304-3835(02)00047-2.

9. Ramos MG, Rabelo FLA, Duarte T, Gazzinelli RT, Alvarez-Leite Jl. Butyrate induces apoptosis in murine macrophages via caspase-3, but independent of autocrine synthesis of tumor necrosis factor and nitric oxide. Braz J Med Biol Res. 2002; 35(2):161-73. doi: 10.1590/S0100879X2002000200004.

10. Tabuchi Y, Arai Y, Kondo T, Takeguchi N, Asano S. Identification of genes responsive to sodium butyrate in colonic epithelial cells. Biochem Biophys Res Comm. 2002; 293(8):1287-94. doi: 10.1016/ S0006-291X(02)00365-0.

11. Neoptolemos JP, Husband D, Imray C, Rowley S, Lawson N. Arachidonic acid and docosahexaenoic acid are increased in human colorectal cancer. Gut. 1991; 32(3):278-281. doi: 10.1136/gut.32.3.278.

12. Hendrickse CW, Kelly RW, Radley S, Donovan IA, Keighley MR, Neoptolemos JP. Lipid peroxidation and prostaglandins in colorectal cancer. Br J Surg. 1994; 81(8):1219-23. doi: 10.1002/bjs. 1800810 849.

13. Fernandez-Banares F, Esteve M, Navarro E, Cabre E, Boix J, Abad-Lacruz A, et al. Changes of the mucosal n3 and n6 fatty acid status occur early in the colorectal adenoma-carcinoma sequence. Gut. 1996; 38(2):254-9.

14. Baro L, Hermoso JC, Nunez MC, Jimenez-Rios JA, Gil A. Abnormalities in plasma and red blood cell fatty acid profiles of patients with colorectal cancer. Br J Cancer. 1998; 77(11):1978-83.

15. Rodrigues MAM, Silva LAG, Salvadori DMF, Camargo JLV, Montenegro MR. Aberrant crypt foci and colon cancer: comparison between a short and medium-term bioassay for colon carcinogenesis using dimethylhydrazine in Wistar rats. Braz J Med Biol Res. 2002; 35(3):351-5. doi: 10.1590/S0100-879X2002000300010.

16. Bird RP. Observation and quantification of aberrant crypts in the murine colon treated with a colon carcinogen: preliminary findings. Cancer Lett. 1987; 37(2):147-51. 
17. Portugal LR, Fernandes LR, Cesar GC, Santiago HC, Oliveira DR, Silva NM, et al. Infection with Toxoplasma gondii increases atherosclerotic lesion in ApoE-deficient mice. Infect Immun. 2004; 72(6):3571-6. doi: 10.1128/IAI.72.6.3571-3576. 2004

18. Hur K, Kim JR, Yoon BI, Lee JK, Choi JH, Oh GT, et al. Overexpression of cyclin D1 and cyclin E in 1,2-dimethylhydrazine dihydrochloride-induced rat colon carcinogenesis. J Vet Sci. 2000; 1(2): 121-6.

19. Folch J, Lees M, Sloane Stanley GH. A simple method for the isolation and purification of total lipides from animal tissues. J Biol Chem. 1957; 226(1):497-509.

20. Hartman L, Lago RC. Rapid preparation of fatty acid methyl esters from lipids. Lab Pract. 1973; 22(6):475-6.

21. Tangerman A, Nagengast FM. A gas chromatographic analysis of fecal short-chain fatty acids, using the direct injection method. Anal Biochem. 1996; 236(8):1-8. doi: 10.1006/abio.1996.0123.

22. Perrin $P$, Pierre F, Patry $Y$, Champ $M$, Berreur $M$, Pradal $\mathrm{G}$, et al. Only fibres promotiong a stable butyrate producing colonic ecosystem decrease the rate of aberrant crypt foci in rats. Gut. 2001; 48(1): 53-61. doi: 10.1136/gut.48.1.53.

23. Freeman HJ. Effect of differing concentrations of sodium butyrate on 1,2-dimethylhydrazineinduced rat intestinal neoplasia. Gastroenterology. 1986; 91(3):596-602.

24. Dang J, Wang Y, Doe WF. Sodium butyrate inhibits expression of urokinase and its receptor mRNAs at both transcription and pos-transcription levels in colon cancer cells. FEBS Lett. 1995; 359(2-3): 147-50. doi: 10.1016/0014-5793(95)00029-9

25. Siavoshian S, Segain JP, Kornprobst M, Bonnet C, Cherbut C, Galmiche JP, et al. Butyrate and trichostatin $A$ on the proliferation/differentiation of human intestinal epithelial cells: induction of cyclin D3 and p21 expression. Gut. 2000; 46(4): 507-14. doi: 10.1136/gut.46.4.507.
26. Douillard JY, Bennouna J, Vavasseur F, DeporteFety R, Thomare P, Giacalone F, et al. Phase I trial of interleukin-2 and high-dose arginine butyrate in metastatic colorectal cancer. Cancer Immunol Immunother. 2000; 49(1):56-61.

27. Edelman MJ, Bauer K, Khanwani S, Tait N, Trepel J, Karp J, et al. Clinical and pharmacologic study of tributyrin: an oral butyrate prodrug. Cancer Chemother Pharmacol. 2003; 51(5):439-44. doi: 10.1007/s00280-003-0580-5.

28. Turner ND, Zhang J, Davidson LA, Lupton JR, Chapkin RS. Oncogenic ras alters sensitivity of mouse colonocytes to butyrate and fatty acid mediated growth arrest and apoptosis. Cancer Lett. 2002; 186(1):29-35. doi: 10.1016/S0304-3835 (02)00325-7.

29. Otori K, Sugiyama K, Fukushima S, Esumi H. Expression of the cyclin D1 gene in rat colorectal aberrant crypt foci and tumors induced by azoximethane. Cancer Lett. 1999; 140(1):99-104. doi: 10.1016/S0304-3835(99)00058-0.

30. Siavoshian S, Blottière HM, Cherbut C, Galmiche JP. Butyrate stimulates cyclin D and p21 and inhibits cyclin-dependent kinase 2 expression in HT-29 colonic epithelial cells. Biochem Biophys Res Comm. 1997; 232(1):169-72. doi: 10.1006/ bbrc.1997.6255.

31. Archer SY, Meng S, Shei A, Hodin RA. p21WAF1 is required for butyrate-mediated growth inhibition of human colon cancer cells. Proc Natl Acad Sci USA. 1998; 95(12):6791-6.

32. Field CJ, Angel A, Clandinin MT. Relationship of diet to the fatty acid composition of human adipose tissue structural and stored lipids. Am J Clin Nutr. 1985; 42(66):1206-20.

33. Topping DL, Clifton PM. Short-chain fatty acids and human colonic function: roles of resistant starch and nonstarch polysaccharides. Physiol Rev. 2001; 81(3):1031-64.

Received on: 8/10/2007

Final version resubmitted on: 30/9/2008 Approved on: 9/3/2009 